\title{
O gênero Lejeunea Libert (Lejeuneaceae) no Estado da Bahia, Brasil ${ }^{1}$
}

\author{
Cid José Passos Bastos ${ }^{2,4}$ e Olga Yano ${ }^{3}$
}

Recebido: 24.04.2008; aceito: 14.05.2009

ABSTRACT - (The genus Lejeunea Libert (Lejeuneaceae) from Bahia State, Brazil). In this paper 21 species of the genus Lejeunea Libert are reported from Bahia. A key to the species, as well as commentaries and data from habitat and substrates are given for each species. Illustrations for some species are provided. Lejeunea laetevirens Nees \& Mont. and Lejeunea flava (Sw.) Nees were the most common species, with large ecological amplitude, occurring in various habitats and substrates. Key words: Brioflora, Lejeuneeae, Marchantiophyta

RESUMO - (O gênero Lejeunea Libert (Lejeuneaceae) no Estado da Bahia, Brasil). São apresentadas 21 espécies pertencentes ao gênero Lejeunea Libert ocorrentes no Estado da Bahia. Chave para identificação das espécies, bem como comentários e dados referentes ao habitat e substratos colonizados são apresentados para cada espécie. Ilustrações são fornecidas para algumas espécies. Lejeunea laetevirens Nees \& Mont. e Lejeunea flava (Sw.) Nees foram as espécies com maior número de ocorrência e com maior amplitude ecológica, ocorrendo em diferentes tipos de ambiente e substratos.

Palavras-chave: Brioflora, Lejeuneeae, Marchantiophyta

\section{Introdução}

Lejeunea Libert é o mais complexo e maior gênero da família Lejeuneaceae, e apresenta estreitas relações com Taxilejeunea (Spruce) Schiffn. e Microlejeunea Steph., este último sendo reconhecido pela maioria dos autores norte-americanos como um subgênero (Schuster 1980).

O gênero está amplamente distribuído nas Regiões Neotropical, Paleotropical e Holártica. Mundialmente são reconhecidos para o gênero ca. 100 espécies (Gradstein \& Costa 2003). Para o Brasil foram reportadas 29 espécies (Gradstein \& Costa 2003, Reiner-Drehwald \& Porto 2007). O gênero está sendo revisado pela Dra. M.E. Reiner-Drehwald, da Universidade de Göttigen, Alemanha, e o número estimado para o neotrópico ainda não está definido. Em sua chave preliminar para o gênero Lejeunea no Brasil, refere 41 espécies (Reiner-Drehwald 2007).

Pode ser reconhecido pelos seguintes caracteres: (a) ramos vegetativos unicamente do tipo-Lejeunea; (b) inovação com padrão lejeuneóide (o primeiro segmento do ramo é sempre um filídio lateral basiscópico); (c) primeiro dente do lóbulo desenvolvido, de modo que a papila hialina é sempre proximal a este; (d) anfigastros bífidos, raramente inteiros; (e) merófito ventral com duas células de largura; (f) perianto com cinco quilhas; (g) ausência de ocelos na quase totalidade das espécies. Os demais caracteres vegetativos e reprodutivos são extremamente variáveis, o que torna difícil a taxonomia do gênero, como margem dos filídios inteira ou denteada; lóbulo bem desenvolvido ou reduzido; células com trigônios grandes ou pequenos, ou ainda, indistintos; espessamentos intermediários presentes ou ausentes; quilhas do perianto lisas, crenuladas, denteadas a laciniadas.

O objetivo do trabalho é discutir os aspectos florísticos do gênero Lejeunea no estado da Bahia, sua distribuição e amplitude ecológica, além de apresentar comentários sobre os caracteres morfológicos importantes para o reconhecimento das espécies.

\section{Material e métodos}

Foi estudado um total de 347 exemplares depositados nos Herbários Alexandre Leal Costa (ALCB), Herbário do Centro de Pesquisas do Cacau (CEPEC), Herbário da Universidade Estadual de

1. Parte da Tese de Doutorado do primeiro autor

2. Universidade Federal da Bahia, Instituto de Biologia, Departamento de Botânica, Laboratório de Taxonomia de Briófitas. Campus de Ondina, 40170-280 Salvador, Bahia, Brasil

3. Instituto de Botânica, Seção de Briologia e Pteridologia, Caixa Postal 3005, 01061-970 São Paulo, SP, Brasil

4. Autor para correspondência: cjpbasto@ufba.br 
Feira de Santana (HUEFS) e Herbário Científico do Estado "Maria Eneyda P. Kauffmann Fidalgo" (SP), procedentes de coletas realizadas no estado da Bahia. A maior parte do material examinado compreende coletas realizadas nas regiões Extremo Sul, Litoral Sul, Recôncavo Sul e Chapada Diamantina (CEI/ CONDER 1994). A nomenclatura segue Gradstein et al. (2003) para a Tribo Lejeuneeae, Gradstein \& Costa (2003) e Reiner-Drehwald (1999, 2007) para as demais espécies. Os dados de distribuição na Bahia, hábitat e briocenose foram obtidos do material examinado. O termo "briocenose" refere-se à classificação das briófitas de acordo com o substrato colonizado, adaptado de Fudali (2001). A amplitude ecológica e o espectro ecológico dos táxons encontrados foram estabelecidos a partir dos dados sobre o ambiente e briocenose. Amplitude ecológica é, aqui, entendida como a variabilidade de ambientes em que dado táxon ocorreu, e o espectro ecológico como a variabilidade de substratos colonizados, considerando a briocenose encontrada (Fudali 2000, 2001). A classificação da vegetação segue Veloso et al. (1991), exceto para "Sistema Agroflorestal" (cabruca: plantação de cacau não manejada em áreas de floresta ombrófila) e "Fragmento Florestal Urbano", que corresponde aos fragmentos de mata que existem na periferia ou em áreas do ambiente urbano, por serem termos mais usuais, ou com especificidade, os quais não constam do sistema de classificação da vegetação brasileira; "Zona Urbana" corresponde aos ambientes citadinos. A distribuição geográfica foi obtida em Reiner-Drehwald (2000), Reiner-Drehwald \& Goda (2000), Gradstein \& Costa (2003), Yano (2006), Reiner-Drehwald \& IlkiuBorges (2007) e Reiner-Drehwald \& Porto (2007). O método de estudo e preparação do material seguiu Bastos \& Yano (2006). Para a elaboração das chaves foram utilizados os caracteres observados a partir do material examinado. As espécies estão listadas em ordem alfabética. As espécies foram identificadas com base nas publicações de Reiner-Drehwald (2000), Reiner-Drehwald \& Goda (2000), ReinerDrehwald \& Ilkiu-Borges (2007), Reiner-Drehwald (2007), Reiner-Drehwald \& Pôrto (2007) e Reiner-
Drehwald \& Schäfer-Verwimp (2008). É apresentada para cada espécie uma breve caracterização morfológica, exceto para Lejeunea oligoclada Spruce, em que é apresentada descrição completa. Ilustrações são fornecidas para algumas espécies que são pouco comuns ou que foram ilustradas em poucas publicações.

\section{Resultados e Discussão}

\section{Lejeunea Libert}

Gametófitos verdes, verde-escuros a verdeamarelados quando secos, ramificados, ramos do tipoLejeunea. Córtex do caulídio apresentando sete fileiras de células, células medulares em número variável, de 3-20. Filídios patentes a ereto-patentes, ou ainda esquarrosos; lobo oblongo-ovalado a ovalado, margem inteira, crenulada a denteada, ápice arredondado a obtuso ou agudo; células com paredes delgadas a espessas, trigônios e espessamentos intermediários presentes ou ausentes; oleocorpos pequenos, homogêneos a segmentados, vários por células; ocelos, em geral, ausentes, raramente presentes; lóbulo variável, inflado ou reduzido, ovalado, dente apical pequeno a alongado, unicelular a pluricelular, unisseriado a bisseriado, obtuso, não acuminado; papila hialina proximal ao primeiro dente. Anfigastros bífidos, raramente inteiros, arredondados a orbiculares, imbricados a distanciados, lobos agudos, triangulares, cuspidados a lanceolados. Merófito ventral com duas células de largura. Monóicas ou dióicas. Androécio em curto ramo lateral; brácteas bilobadas, em 2-5 pares, imbricadas, infladas; bractéolas 1-2 na base ou ao logo do ramo. Ginoécio terminal no ramo principal ou em curto ramo lateral; inovações geralmente presentes, com sequiência lejeuneóide; brácteas bilobadas, o lóbulo plano e estreito; bractéolas bífidas, orbiculares; perianto obovado, geralmente 5-quilhado, quilhas inteiras, crenuladas, denteadas ou laciniadas (Schuster 1980, Reiner-Drehwald 2000).

No estado da Bahia foram reconhecidas, até o momento, 21 espécies pertencentes ao gênero Lejeunea. 
Chave para as espécies do gênero Lejeunea encontradas na Bahia

1. Filídios com ocelos Lejeunea huctumalcensis

1. Filídios sem ocelos

2. Dente do lóbulo com 3-9 células de comprimento, 1-2 células de largura

3. Dente do lóbulo com 3-5 células de comprimento, 2 células de largura Lejeunea setiloba

3. Dente do lóbulo com 7-9 células de comprimento, 1 célula de largura Lejeunea trinitensis

2. Dente do lóbulo com 1-2 células de comprimento, uma célula de largura

4. Plantas caracteristicamente com reprodução vegetativa por filídios caducos

5. Cutícula fortemente papilosa; anfigastros com sinus profundo (mais do que $2 / 3$ do compr. do anfigastro), lunado a largamente agudo Lejeunea perpapillosa

5. Cutícula lisa a finamente papilosa; anfigastros com sinus pouco profundo (ca. $1 / 3$ a $1 / 2$ do compr. do anfigastro), agudo

6. Filídios caducos em geral portando rizóides na margem Lejeunea tapajosensis

6. Filídios caducos sem rizóides na margem, em geral com gemas ou regenerantes

7. Filídios patentes, imbricados, ápice arredondado, cutícula lisa ........ Lejeunea phyllobola

7. Filídios patentes a suberetos, contíguos, ápice arredondado a agudo, cutícula finamente papilosa Lejeunea oligoclada

4. Plantas sem reprodução vegetativa por filídios caducos

8. Plantas pequenas, $0,3-0,6 \mathrm{~mm}$ larg.

9. Cutícula lisa; anfigastros fortemente adpressos ao caulídio, célula apical dos lobos com paredes muito finas, às vezes colapsadas Lejeunea filipes

9. Cutícula finamente papilosa; anfigastros não adpressos ao caulídio, célula apical dos lobos com paredes firmes, não colapsadas Lejeunea laetevirens

8. Plantas maiores, acima de $0,6 \mathrm{~mm}$ larg.

10. Perianto com quilhas laciniadas a denteadas

11. Lobos dos anfigastros com margem denteada, raramente inteira; cutícula finamente papilosa Lejeunea boryana

11. Lobos dos anfigastros com margem inteira; cutícula lisa 12. Ápice do filídio apiculado Lejeunea grossitexta

12. Ápice do filídio arredondado

13. Rostro do perianto longo, acima de $100 \mu \mathrm{m}$ compr.; quilhas laciniadas Lejeunea grossiretis

13. Rostro do perianto curto, menor que $100 \mu \mathrm{m}$ compr., quilhas sem lacínias, denteadas Lejeunea elliottii

10. Perianto com quilhas sem lacínias, ou estas são muito curtas, em geral fortemente crenuladas ou inteiras

14. Lobos dos anfigastros cuspidados; cutícula finamente papilosa; quilhas do perianto crenuladas, às vezes com lacínias curtas Lejeunea controversa

14. Lobos dos anfigastros não cuspidados; cutícula lisa; quilhas do perianto sempre sem lacínias

15. Anfigastros grandes, 2-2,5(-3) vezes a largura do caulídio

16. Ápice dos filídios agudo a apiculado; anfigastros reniformes a ovalados, base fortemente cordada Lejeunea cerina

16. Ápice dos filídios arredondado a obtuso; anfigastros orbiculares, ovalados a oblongos, base não cordada, arredondada a cuneada

17. Filídios com margem fortemente crenulada; anfigastros ovalados, lobos com margem fortemente crenulada, base arredondada Lejeunea immersa

17. Filídios com margem inteira; anfigastros ovalados, orbiculares a oblongos, lobos com margem inteira, base cuneada 
18. Anfigastros orbiculares a ovalados; células com 1-3 espessamentos intermediários; androécio com bractéolas ao longo do ramo Lejeunea cancellata

18. Anfigastros ovalados; células sem espessamentos intermediários; androécio com bractéolas apenas na base do ramo Lejeunea flava

15. Anfigastros pequenos a medianos, ca. 1-1,5 vezes a largura do caulídio

19. Anfigastros com sinus lunado, lobos lanceolados .............. Lejeunea magnoliae

19. Anfigastros com sinus agudo, lobos não lanceolados, triangulares

20. Anfigastros orbiculares, lobos patentes a suberetos; perianto oblongo, em geral estipitado Lejeunea laeta

20. Anfigastros ovalados a oblongos, lobos não patentes, planos; perianto obovado, não estipitado Lejeunea caulicalyx

Lejeunea boryana Mont., Ann. Sci. Nat. Bot., sér. 2, 9: 47.1838.

Descrição e ilustração: Reiner-Drehwald \& Goda (2000).

A espécie apresenta cutícula papilosa, anfigastros com sinus largamente agudo a lunado, com os lobos geralmente denteados, às vezes, dentes ausentes; perianto ornamentado, com quilhas laciniadas.

Material examinado: BRASIL. BAHIA: Igrapiúna, Reserva Ecológica da Michelin, 1348'08"S, 39¹0'03'W, Mata da Vila Cinco, 14-II-2006, C. Bastos 4359 (ALCB); idem, Mata da Cachoeira da Pancada Grande, 21-IV-2006, C. Bastos 4550 (ALCB); idem, Mata do Meio, 7-II-2007, C. Bastos 4949 (ALCB); idem, Mata de Pacangê, 8-II-2007, C. Bastos 5001 p.p. (ALCB).

Distribuição: Antilhas e América do Sul. Brasil: AC, AM, BA, PA, RR.

Ambiente: Floresta Ombrófila.

Briocenose: corticícola e rupícola.

$\mathrm{Na}$ Bahia só foi encontrada no Litoral Sul, em floresta ombrófila, em apenas uma localidade.

*Lejeunea cancellata Nees \& Mont. in Montagne, in Ramón de la Sagra, Hist. Phys. Cuba 9: 472. 1842.

Descrição e ilustração: Reiner-Drehwald (2000).

A espécie apresenta os anfigastros grandes a medianos, 272-370 $\mu \mathrm{m}$ de larg., orbiculares a ovalados, sinus agudo, base cuneada; células com espessamentos intermediários evidentes, 1-3; monóica. Androécio com 2-10 pares de brácteas, e bractéolas distribuídas ao longo do ramo; ginoécio com brácteas inteiras, perianto obovado, 5-quilhado. Reprodução vegetativa por ramos e filídios caducos, gemas ocasionalmente produzidas na margem dos filídios caducos.

Material examinado: BRASIL. BAHIA: Correntina, ca. 100 km a W de Correntina, 1-II-1967, D.M. Vital 1139 (SP); Cravolândia, 12 km ao S de Cravolândia, 17VIII-1976, D.M. Vital 6527 (SP); Itabuna, CEPLAC, 25-I-1980, O. Yano 2317 (SP).

Distribuição geográfica: América do Norte e América do Sul. Brasil: BA, MS, RJ, SC, SP.

Ambiente: Floresta Estacional.

Briocenose: corticícola.

Até o momento, a sua distribuição na Bahia é restrita a duas localidades, ambas no Sudoeste do Estado.

Lejeunea caulicalyx (Steph.) E. Reiner \& Goda, J. Hattori Bot. Lab. 89: 13. 2000.

Descrição e ilustração: Reiner-Drehwald \& Goda (2000).

A espécie apresenta filídios imbricados, lobo ovalado a ovalado-oblongo, margem anterior arqueada, inteira, margem posterior reta, inteira, ápice arredondado a obtuso; lóbulos ovalados, inflados, freqüentemente reduzidos; anfigastros oblongos a ovalados, pequenos, 192-232 um larg., sinus agudo, base cuneada, distanciados; monóica. Androécio em curtos ramos, bractéolas apenas na base; ginoécio com brácteas inteiras, perianto 5-quilhado, quilhas levemente expandidas acima, crenuladas. 
Material examinado: BRASIL. BAHIA: Jaguaripe, Jacuruna, 1302'02”S, 38 50'50”'W, 29-VI-1991, C. Bastos 253 (ALCB); Salvador, 12 ${ }^{\circ} 58^{\prime} 57^{\prime \prime}$, 38 30'18"W, Parque Metropolitano de Pituaçu, 28-X-1997, C. Bastos 990 (ALCB); idem, Campus Universitário-UFBA, Ondina, 23-III-2004, C. Bastos 3862 (ALCB); São Sebastião do Passé, Lamarão do Passé, 12³5'55'S, 38²3'57'W, 26-X-1998, S.B. Vilas Bôas-Bastos 277 (ALCB); Alagoinhas, 1205'34'S, 38²5'03'W, Campus II -UNEB, 13-IX-1995, S.B. Vilas Bôas-Bastos et al. 135 (ALCB); Camaçari, Pólo Petroquímico de Camaçari, 12³8'51'S, 38¹8'47'W, área antrópica industrial, 18-X-1998, S.B. Vilas BôasBastos 182 (ALCB); Eunápolis, Estação Veracruz, $16^{\circ} 22^{\prime}$ S, 39¹0'W, 10-VI-1999, S.B. Vilas BôasBastos \& C. Bastos 562 (ALCB); Itacaré, Engenhoca, $14^{\circ} 20^{\prime} 58^{\prime}$ 'S, 38 59'59"W, ca. $12 \mathrm{~km}$ ao sul de Itacaré, 8-II-2001, C. Bastos \& S.B. Vilas Bôas-Bastos 2379 (ALCB); Santa Cruz Cabrália, Fragmento Carabranca, $16^{\circ} 16^{\prime} \mathrm{S}, 39^{\circ} 02^{\prime} \mathrm{W}, 9-\mathrm{III}-2001$, C. Bastos \& S.B. Vilas Bôas-Bastos 2646 (ALCB); Mata de São João, 12³4'49'S, 38²2'30'W, estrada do gasoduto, 10-VIII-2001, C. Bastos \& S.B. Vilas Bôas-Bastos 3142 (ALCB); Miguel Calmon, Serra do Campo Limpo,

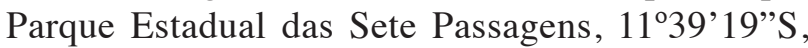
40 53'00'W, Trilha do Vale do Jajai, 600-900 m alt., 21-IV-2003, C. Bastos \& S.B. Vilas Bôas-Bastos 3335 (ALCB); Igrapiúna, Reserva Ecológica da Michelin, $13^{\circ} 48^{\prime} 08^{\prime}$ 'S, 39¹0'03'W, Mata da Vila Cinco, 14-II2006, C. Bastos 4344; S.B. Vilas Bôas-Bastos 2020 (ALCB); idem, Mata da Cachoeira da Pancada Grande, 21-IV-2006, C. Bastos 4428 (ALCB).

Distribuição geográfica: América Central e Brasil: AC, BA, ES, MS, MT, PA, PE, PR, RJ, RR, SP (como Lejeunea glaucescens Gottsche).

Ambiente: Floresta Ombrófila, Savana, Fragmento Florestal Urbano e Zona Urbana.

Briocenose: corticícola, epíxila e terrícola.

Os espécimes estudados no Estado da Bahia haviam sido tratados anteriormente como Lejeunea glaucescens Gottsche (C. Bastos, dados não publicados, Bastos \& Vilas Bôas-Bastos 2000). No entanto, os exemplares oriundos da Estação Veracruz e Reserva Ecológica da Michelin, correspondem mais ao conceito de Lejeunea caulicalyx. De acordo com Reiner-Drehwald (dados não publicados), os espécimes descritos e ilustrados por Schuster (1980) como Lejeunea glaucescens Gottsche, correspondem a Lejeunea caulicalyx.
A espécie tem ampla distribuição na Bahia, ocorrendo em variados tipos de vegetação e em ambiente urbano, crescendo em mais de um tipo de substrato, incluindo o solo.

Lejeunea cerina (Lehm. \& Lindenb.) Gottsche in Lindenb. \& Nees, Syn. Hep.: 391. 1845.

Descrição e Ilustração: Alvarenga et al. (2007).

A espécie caracteristicamente apresenta anfigastros grandes (2,5-3 vezes a largura do caulídio), reniformes a ovalados, imbricados a contíguos, base cordada; filídios com lobo ovalado, margem inteira, ápice curto-apiculado a agudo.

Material examinado: BRASIL. BAHIA: Igrapiúna, Reserva Ecológica da Michelin, $13^{\circ} 48^{\prime} 08^{\prime}$ S, 39¹0'03"W, Mata da Vila Cinco, 14-II-2006, C. Bastos 4315 (ALCB); Abaíra, Catolés, Serra do Barbado, Mata da Forquilha, $1.594 \mathrm{~m}$ alt., 1317'27'S, 4154'015”W, 5-IX-2008, C. Bastos 5114 (ALCB).

Distribuição geográfica: América Central e América do Sul. Brasil: AC, BA, ES, PE, RJ, SP.

Ambiente: Floresta Ombrófila e Floresta Estacional.

Briocenose: corticícola e rupícola.

$\mathrm{Na}$ Bahia, até o momento, encontrada apenas no Sul e Sudoeste do Estado, em floresta ombrófila e estacional montana, crescendo em mais de um tipo de substrato, em maior proporção sobre rochas.

Lejeunea controversa Gottsche in Gottsche \& Rabenhorst, Hep. Europ.: 556. 1872.

Figuras 1-7

A espécie apresenta cutícula papilosa, filídios com lobo ovalado a oblongo-ovalado, ápice arredondado, curto-apiculado a obtuso; anfigastros caracteristicamente com lobos cuspidados, sinus agudo, base arredondada. Autóica; androécio com 2-4 pares de brácteas, bractéolas apenas na base do ramo; ginoécio com brácteas inteiras, perianto 5-quilhado, quilhas levemente expandidas no ápice, fortemente crenuladas; inovação, às vezes com padrão taxilejeuneóide (repetidamente fértil).

Material examinado: BRASIL. BAHIA: Eunápolis, Estação Veracruz, $16^{\circ} 22^{\prime} \mathrm{S}, 39^{\circ} 10^{\prime} \mathrm{W}, 10$-VI1999, S.B. Vilas Bôas-Bastos \& C. Bastos 523 (ALCB); Igrapiúna, Reserva Ecológica da Michelin, $13^{\circ} 48^{\prime} 08^{\prime}$ 'S, 39¹0'03"W, Mata da Vila Cinco, 14II-2006, C. Bastos 4378 (ALCB); idem, Mata da 


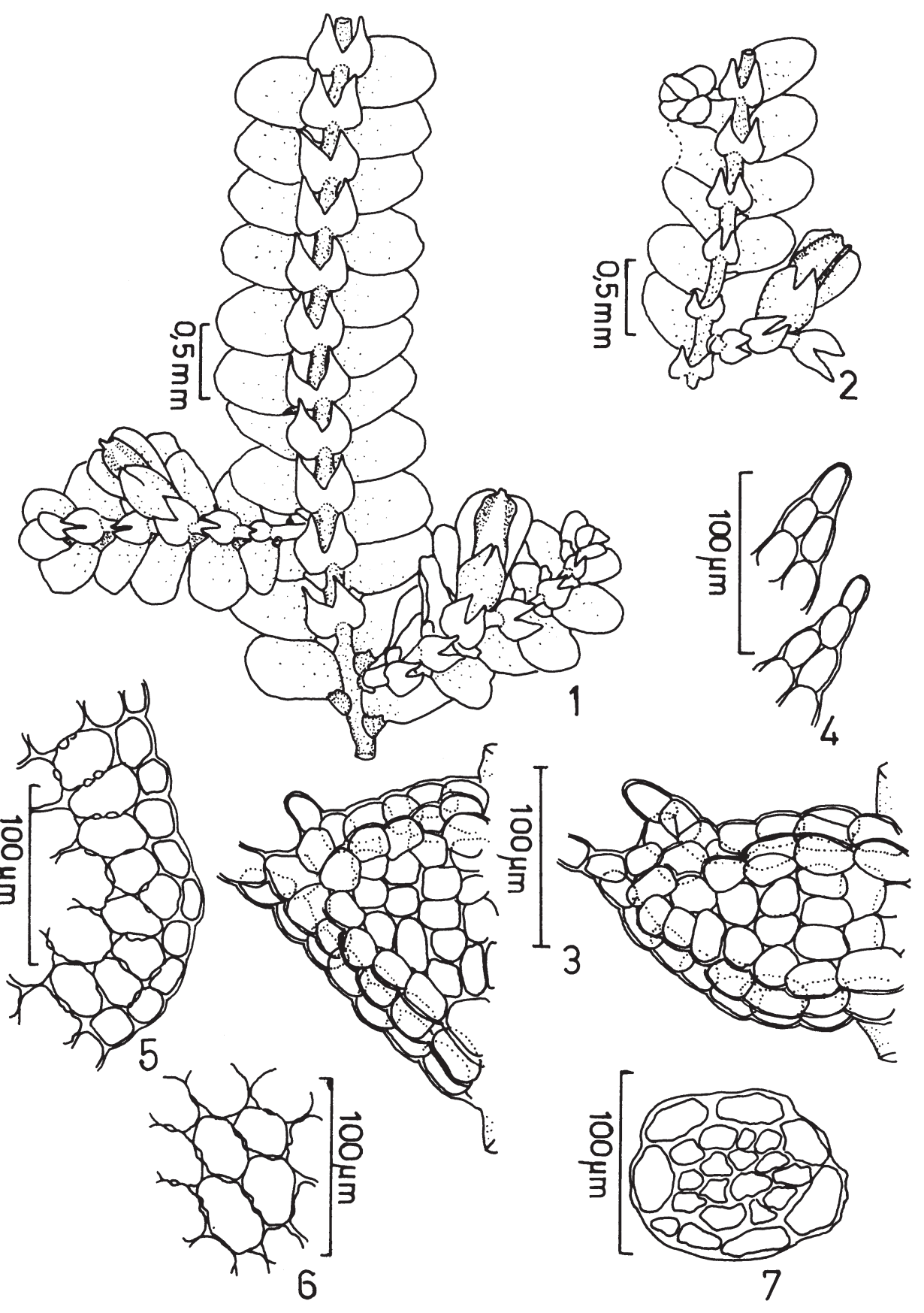

Figuras 1-7. Lejeunea controversa Gottsche. 1. Gametófito, vista ventral. 2. Parte do gametófito com ginoécio, vista ventral. 3. Lóbulos. 4. Ápices do anfigastro. 5. Margem do lobo do filídio. 6. Células da lâmina do filídio. 7. Corte transversal do caulídio (C. Bastos 475).

Figures 1-7. Lejeunea controversa Gottsche. 1. Shoot, ventral view. 2. Shoot, dorsal view. 3. Portions of shoot with with gynoecium, ventral view. 3. Lobules. 4. Underleaf apices. 5. Lobe margin of leaf. 6. Laminal cells. 7. Stem cross-section (C. Bastos 475). 
Cachoeira da Pancada Grande, 21-II-2006, C. Bastos 4583 (ALCB); idem, Mata do Meio, 7-II-2007, C. Bastos 4980 (ALCB); idem, Mata de Pacangê, 8-II2007, C. Bastos 5062 (ALCB).

Distribuição geográfica: América Central e América do Sul. Brasil: AC, BA, MS, PA, SP.

Ambiente: Floresta Ombrófila.

Briocenose: corticícola, epífila e rupícola.

Embora a sua ocorrência na Bahia esteja restrita à região sul do Estado, a espécie é muito freqüente nas florestas ombrófilas, crescendo sobre caules, folhas e rochas.

Lejeunea elliottii Spruce, J. Linn. Soc. Bot. 30: 346. 1895.

Descrição e ilustração: Bastos \& Yano (2004).

A espécie apresenta filídios com margem fortemente crenulada, anfigastros pequenos, 60-132 um larg., sinus agudo, base cuneada, distanciados. Autóicos; androécio curto, com 2-3 pares de brácteas, bractéolas apenas na base do ramo; ginoécio com brácteas fortemente crenuladas, perianto 5-quilhado, quilhas expandidas no ápice, fortemente crenuladas a denteadas.

Material examinado: BRASIL. BAHIA: Eunápolis, Estação Veracruz, $16^{\circ} 22^{\prime}$ S, 39010'W, 8-IX-1999, C. Bastos \& S.B. Vilas Bôas-Bastos 1628 (ALCB); Igrapiúna, Reserva Ecológica da Michelin, 1348'08'S, $39^{\circ} 10^{\prime} 03^{\prime \prime} \mathrm{W}$, Mata da Vila Cinco, 14-II-2006, S.B. Vilas Bôas-Bastos 1825 (ALCB).

Distribuição geográfica: América Central e América do Sul. Brasil: BA.

Ambiente: Floresta Ombrófila.

Briocenose: epíxila e rupícola.

No Brasil só há registro para a Bahia (Bastos \& Yano 2004), encontrada apenas em florestas ombrófilas do sul do Estado, em poucas amostras.

Lejeunea filipes Spruce, Trans. \& Proc. Bot. Soc. Edinburgh 15: 275. 1884.

Descrição e ilustração: Bastos \& Yano (2004).

Aespécie apresenta filídios contíguos a imbricados, levemente ereto-patentes, margem inteira, anfigastros pequenos, 56-60 $\mu \mathrm{m}$ larg., célula apical dos lobos com paredes finas e em geral colapsadas. Autóicos; androécio com 2-3 pares de brácteas, bractéolas na base do ramo; ginoécio com brácteas inteiras, perianto obovado, 5-quilhado. Lejeunea autoica R.M. Schust. é um provável sinônimo.

Material examinado: BRASIL. BAHIA: Santa Terezinha, povoado de Pedra Branca, Serra da Jibóia, 1252'S, $39^{\circ} 28^{\prime} \mathrm{W}, 4-\mathrm{III}-2001$, E.B. Valente et al. 57 p.p. (HUEFS); idem, 12-III-2002, C. Bastos 3177, 3234 (ALCB); Eunápolis, Estação Veracruz, $16^{\circ} 22$ 'S, 39¹0'W, 9-VI-1999, S.B. Vilas Bôas-Bastos \& C. Bastos 972 (ALCB); Igrapiúna, Reserva Ecológica da Michelin, 1348'08'S, 39 $19^{\circ}$ '03'W, Mata da Vila Cinco, 14-II-2006, C. Bastos 4118 p.p. (ALCB); idem, Mata da Cachoeira da Pancada Grande, 21-IV- 2006, C. Bastos 4466 p.p. (ALCB).

Distribuição geográfica: América do Norte, América Central e América do Sul. Brasil: BA, MS, SP.

Ambiente: Floresta Ombrófila.

Briocenose: corticícola e epífila.

$\mathrm{Na}$ Bahia é pouco representada, com poucas amostras encontradas apenas em duas localidades.

Lejeunea flava (Sw.) Nees, Naturgesch. Eur. Leberm. 3: 277.1838.

Descrição e ilustração: Reiner-Drehwald (2000).

A espécie apresenta filídios patentes, imbricados, margem inteira, anfigastros grandes, 200-280 $\mu \mathrm{m}$ de largura, distanciados, ovalados, lobos agudos, sinus agudo, base arredondada. Autóicos; androécio com 2-4 pares de brácteas, bractéolas apenas na base; ginoécio com brácteas inteiras, perianto obovado, 5-quilhado.

Material examinado: BRASIL. BAHIA: Morro do Chapéu, cachoeira do Ferro Doido, 4-IV-1976, D.M. Vital 6066 (SP); Cravolândia, 17-VIII-1976, D.M. Vital 6529 p.p. (SP); Ilhéus, área da Universidade de Santa Cruz, 16-IX-1991, S.L. Oliveira \& A.C.Messias 179 (ALCB); idem, Ponta da Tulha, 7-X-1995, $C$. Bastos \& S.B. Vilas Bôas 778 (ALCB); Salvador, $12^{\circ} 58^{\prime} 57^{\prime}$ 'S , 38 30'18'W, Horto Florestal do Cabula, 6-VII-1991, C.S.N. Guimarães 17-A p.p. (ALCB); São Francisco do Conde, Monte Recôncavo, 1258'36"S, 38 37'59”'W, Fazenda Engenho Madruga, 19-V1991, C. Bastos 162 (ALCB); Salinas da Margarida, Encarnação, 12 ${ }^{\circ} 55^{\prime}$ '58'S, 3845'25”W, 8-IV-1993, C. Bastos 487 (ALCB); Lamarão do Passé, 12³5'55'S, 38 23'57'W, estrada para São Sebastião do Passé, 22-VIII-1994, C. Bastos 614 (ALCB); Santa Cruz Cabrália, Fragmento Cara-branca, $16^{\circ} 16^{\prime} \mathrm{S}, 39^{\circ} 02^{\prime} \mathrm{W}$, 9-III-2001, C. Bastos \& S.B. Vilas Bôas-Bastos 2637 
(ALCB); São Felipe, 1250'50”S, 3905'22”W, zona urbana, 12-VII-2001, C. Bastos \& S.B. Vilas BôasBastos 3080 (ALCB); Mata de São João, estrada do gasoduto, 12³4'49'S, 38²3'57'W, 10-VIII-2001, C. Bastos \& S.B. Vilas Bôas-Bastos 3135 (ALCB51219); Santa Terezinha, Serra da Jibóia, $12^{\circ} 51^{\prime} \mathrm{S}, 39^{\circ} 28^{\prime} \mathrm{W}$, 2-III-2001, Projeto Reflorar-GAMBA/Fazenda Jequitibá, E.B. Valente et al. s.n. (HUEFS); Mucugê, $13^{\circ} 01^{\prime} 49^{\prime \prime} \mathrm{S}, 41^{\circ} 26^{\prime} 44^{\prime}$ 'W, às margens do rio Cumbuca, 16-I-2002, C. Bastos 3162 (ALCB); Miguel Calmon, Serra do Campo Limpo, Parque Estadual das Sete Passagens, 11'39'19''S, 4053'00'W, 950 m alt., 22IV-2003, C. Bastos \& S.B. Vilas Bôas-Bastos 3718 (ALCB); Igrapiúna, Reserva Ecológica da Michelin, $13^{\circ} 48^{\prime} 08^{\prime}$ 'S, 39¹0'03”'W, Mata da Vila Cinco, 14II-2006, C. Bastos 4236 (ALCB); idem, Mata da Cachoeira da Pancada Grande, 21-IV-2006, C. Bastos 4628 (ALCB); idem, Mata do Meio, 7-II-2007, $C$. Bastos 4891 p.p. (ALCB); idem, Mata de Pacangê, 8-II-2007, C. Bastos 5022 p.p. (ALCB).

Distribuição geográfica: Sudeste da Ásia, África, América do Norte, América Central e América do Sul. Brasil: AC, AM, BA, ES, MG, MS, PA, PB, PE, PR, RJ, RS, SP.

Ambiente: Floresta Ombrófila, Floresta Estacional, Savana, Fragmento Florestal Urbano e Zona Urbana.

Briocenose: corticícola, epífila, epíxila e rupícola.

Lejeunea flava é bem representada no Estado da Bahia, tendo ocorrido em várias localidades, crescendo em diferentes tipos de ambientes e substratos, incluindo o ambiente urbano.

Lejeunea grossiretis (Steph.) E. Reiner \& Goda, J. Hattori Bot. Lab. 89: 27. 2000.

Figuras 8-16

A espécie apresenta filídios ovalados, imbricados, margem inteira, anfigastros ovalados, pequenos, 80$156 \mu \mathrm{m}$ larg., distanciados, lobos agudos, sinus agudo, base cuneada. Autóicos; androécio com 2-4 pares de brácteas, bractéolas apenas na base do ramo; ginoécio com brácteas inteiras, perianto oblongo, 5-quilhado, com rostro caracteristicamente longo, acima de 100 $\mu \mathrm{m}$ de compr.

Material examinado: BRASIL. BAHIA: Eunápolis, Estação Veracruz, $16^{\circ} 22^{\prime}$ 'S, 39¹0'W, 9-VI-1999, S.B. Vilas Bôas-Bastos \& C. Bastos 517 (ALCB); Santa
Cruz Cabrália, Fragmento Cara-branca, $16^{\circ} 16^{\prime} \mathrm{S}$, 3902'W, 9-III-2001, C. Bastos \& S.B. Vilas BôasBastos 2821 (ALCB); Igrapiúna, Reserva Ecológica

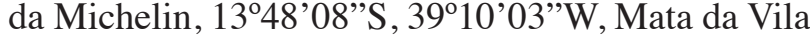
Cinco, 14-II-2006, C. Bastos 4354 (ALCB); idem, Mata da Cachoeira da Pancada Grande, 21-IV-2006, C. Bastos 4578p.p. (ALCB); idem, Mata do Meio, 7-II-2007, C. Bastos 4927 p.p. (ALCB); idem, Mata de Pacangê, 8-II-2007, C. Bastos 4859 (ALCB).

Distribuição geográfica: Brasil: BA, RJ.

Ambiente: Floresta Ombrófila.

Briocenose: corticícola, epíxila e rupícola.

Embora não tenha ampla distribuição na Bahia (só foi encontrada na região sul do Estado), crescendo apenas em floresta ombrófila de terras baixas, apresenta alta ocorrência.

*Lejeunea grossitexta (Steph.) E. Reiner \& Goda, J. Hattori Bot. Lab. 89: 29. 2000.

Descrição e ilustração: Reiner-Drehwald \& Goda (2000).

Apresenta filídios com ápice apiculado, anfigastros pequenos, ca. 1,5-2,0 vezes a largura do caulídio, lobos agudos, sinus agudo, base cuneada; perianto com quilhas fortemente laciniadas.

Material examinado: BRASIL. BAHIA: Abaíra, Catolés, Serra do Barbado, Mata da Forquilha, 1.594

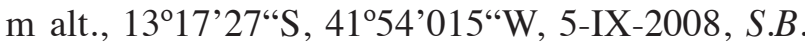
Vilas Bôas-Bastos 2377 (ALCB).

Distribuição geográfica: América do Sul. Brasil: BA, ES, MG, PR, RJ, SC, SP.

Ambiente: Floresta Estacional.

Briocenose: corticícola.

$\mathrm{Na}$ Bahia, até o momento, encontrada apenas no sudoeste do Estado, em floresta estacional montana. Esta é a primeira referência para a Bahia.

Lejeunea huctumalcensis Lindenb. \& Gottsche in Gottsche, Lindenb. \& Nees, Syn. Hepat.: 762. 1847.

Descrição e ilustração: Reiner-Drehwald \& IlkiuBorges (2007).

Apresenta filídios imbricados, margem inteira, anfigastros pequenos, 100-128 $\mu \mathrm{m}$ larg., distanciados, lobos agudos, sinus agudo, base cuneada; ocelos presentes, 1-4 basais, grosseiramente granulosos. Autóicos; androécio com 2-8 pares de brácteas, 


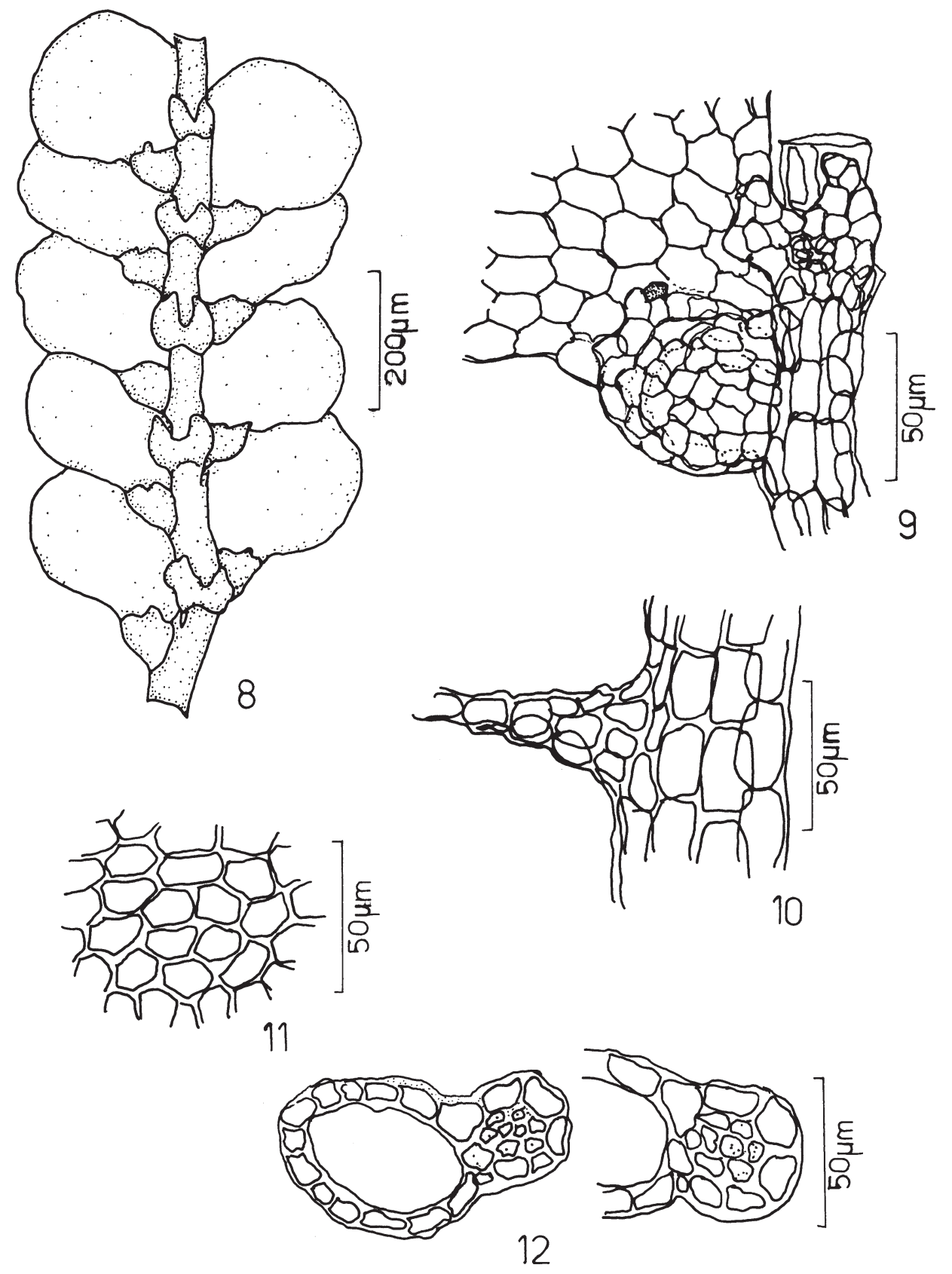

Figuras 8-12. Lejeunea grossiretis (Steph.) E. Reiner \& Goda. 8. Gametófito, vista ventral. 9. Vista do lóbulo e anfigastro. 10. Lóbulo reduzido. 11. Células da lâmina. 12. Cortes transversais do caulídio.

Figures 8-12. Lejeunea grossiretis (Steph.) E. Reiner \& Goda. 8. Shoot, ventral view. 9. Detail of lobule and underleaf. 10. Reduced lobule. 11. Laminal cells. 12. Stem cross-sections. 


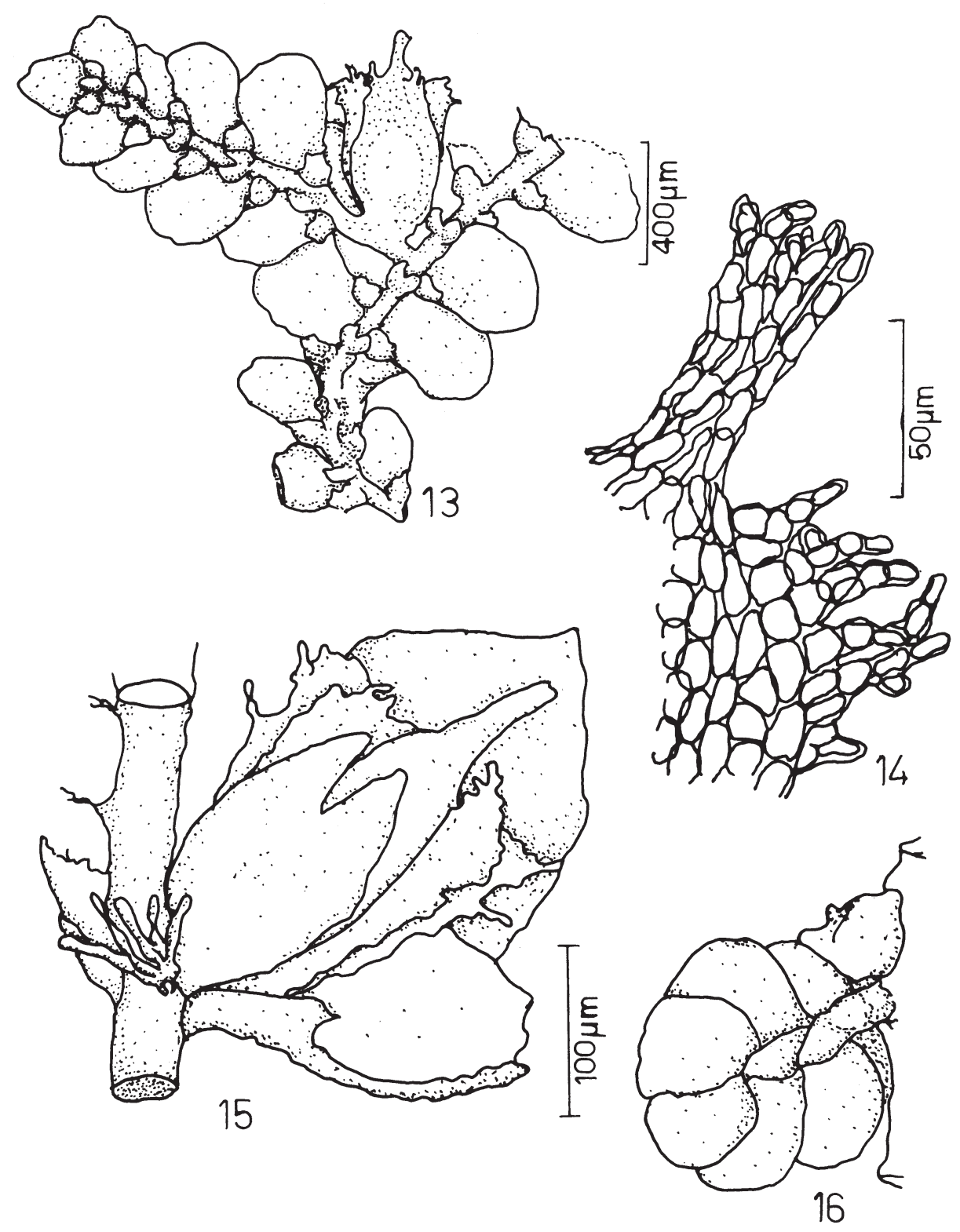

Figuras 13-16. Lejeunea grossiretis (Steph.) E. Reiner \& Goda. 13. Parte do gametófito com ginoécio, vista ventral. 14. Margem e rostro do perianto. 15. Ginoécio, vista ventral. 16. Androécio, vista ventral.

Figures 13-16. Lejeunea grossiretis (Steph.) E. Reiner \& Goda. 13. Portions of shoot with gynoecium, ventral view. 14. Margin and rostrum of perianth. 15. Gynoecium, ventral view. 16. Androecium, ventral view. 
bractéolas na base do ramo; ginoécio com brácteas com margem inteira a irregular, perianto obovado, com lacínias irregulares a ramificadas; reprodução vegetativa por gemas formadas na margem dos filídios.

Material examinado: BRASIL. BAHIA: Eunápolis, Estação Veracruz, 16 22'47'S, 39¹0'20"W, 8-IX1999, C. Bastos \& S.B. Vilas Bôas-Bastos 1644 (ALCB); Santa Cruz Cabrália, Fragmento Carabranca, $16^{\circ} 16^{\prime}$ S, 3902'W, 9-III-2001, C. Bastos \& S.B. Vilas Bôas-Bastos 2659 (ALCB); Igrapiúna, Reserva Ecológica da Michelin, 1348'08"S, 39¹0'03"W, Mata da Vila Cinco, 14-II-2006, $C$. Bastos 4337 (ALCB); idem, Mata da cachoeira da Pancada Grande, 21-IV-2006, C. Bastos 4592 (ALCB); idem, Mata do Meio, 7-II-2007, C. Bastos 4960 p.p. (ALCB); idem, Mata de Pacangê, 8-II-2007, C. Bastos 5067 (ALCB).

Distribuição geográfica: América do Norte, América Central e América do Sul. Brasil: AM, BA, PA.

Ambiente: Floresta Ombrófila.

Briocenose: corticícola.

Lejeunea huctumalcensis é a única espécie do gênero que apresenta ocelos. Até recentemente era conhecida como Ceratolejeunea dussiana (Steph.) G. Dauphin, mas foi sinonimizada por Reiner-Drehwlad \& Ilkiu-Borges (2007). Na Bahia, embora com ocorrência restrita à região sul do Estado, apresenta alta ocorrência, sempre em floresta ombrófila de terras baixas.

Lejeunea immersa Spruce, Trans. Proc. Bot. Soc. Edinburgh 15: 186. 1884.

Figuras 17-25

Apresenta filídios imbricados, caracteristicamente com margem fortemente crenuladas, anfigastros ovalados a largamente ovalados, lobos agudos com margem fortemente crenulada; perianto em geral estipitado, com quilhas crenuladas acima.

Material examinado: BRASIL. BAHIA: Igrapiúna, Reserva Ecológica da Michelin, 1348'08"S, 39¹0'03"W, Mata da Vila Cinco, 14-II-2006, $C$. Bastos 4259 (ALCB); idem, Mata da Cachoeira da Pancada Grande, 21-IV-2006, C. Bastos 4578 (ALCB); idem, Mata do Meio, 7-II-2007, C. Bastos 4984 (ALCB); idem, Mata de Pacangê, 8-II-2007, C. Bastos 5035 (ALCB).
Distribuição geográfica: América do Sul. Brasil: BA.

Ambiente: Floresta Ombrófila.

Briocenose: corticícola, epíxila e rupícola.

Os espécimes estudados no estado da Bahia, com base na "Preliminary key to the genus Lejeunea in Brazil" (Reiner-Drehwlad 2007), serão aqui circunscritos no conceito de Lejeunea immersa. Na Bahia só ocorreu na região sul do Estado, em ambiente de floresta ombrófila de terras baixas.

Lejeunea laeta (Lehm. \& Lindenb.) Gottsche, Linden. \& Nees, Syn. Hepat.: 380. 1845.

Descrição e ilustração: Reiner-Drehwald (2000, como Lejeunea geophila Spruce).

Apresenta filídios ovalados, imbricados, margem inteira, anfigastros rotundos a orbiculares, patentes; perianto oblongo, estipitado, quilhas inteiras a fracamente crenuladas.

Material examinado: BRASIL. BAHIA: Eunápolis, Estação Veracruz, $16^{\circ} 22^{\prime} 47^{\prime}$ 'S, 39¹0'20"W, 9-IX1999, S.B. Vilas Bôas-Bastos \& C. Bastos 1386 (ALCB); Mata de São João, 12³4'49”'S, 38²2'30"W, estrada do gasoduto, 10-VIII-2001, C. Bastos \& S.B. Vilas Bôas-Bastos 3119 (ALCB); São Felipe, $12^{\circ} 50^{\prime} 50^{\prime \prime} S, 39^{\circ} 05^{\prime} 22^{\prime \prime} W$, Serra da Copioba, 12VII-2001, C. Bastos \& S.B. Vilas Bôas-Bastos 3051 (ALCB); Igrapiúna, Reserva Ecológica da Michelin, $13^{\circ} 48^{\prime} 08^{\prime}$ 'S , 39 $9^{\circ} 10^{\prime} 03^{\prime \prime} \mathrm{W}$, Mata de Pacangê, 8-II2007, C. Bastos 5040 p.p. (ALCB).

Distribuição geográfica: América do Sul. Brasil: BA, MG, RJ, SP.

Ambiente: Floresta Ombrófila, Floresta Estacional, Fragmento Florestal Urbano.

Briocenose: epíxila e terrícola.

É bem representada na Bahia, crescendo geralmente em solos ou em troncos caídos.

Lejeunea laetevirens Nees \& Mont. in Ranmón de la Sagra, Hsit. Phys. Cuba, Bot.-Pl. Cell, 9: 469. 1842.

Descrição e ilustração: Reiner-Drehwald (2000).

Apresenta cutícula finamente papilosa, com evidente aversão à água, filídios geralmente eretopatentes, com margem inteira, anfigastros com lobos agudos, em geral com dente lateral. Dióica; perianto obovado, 5-quilhado. 


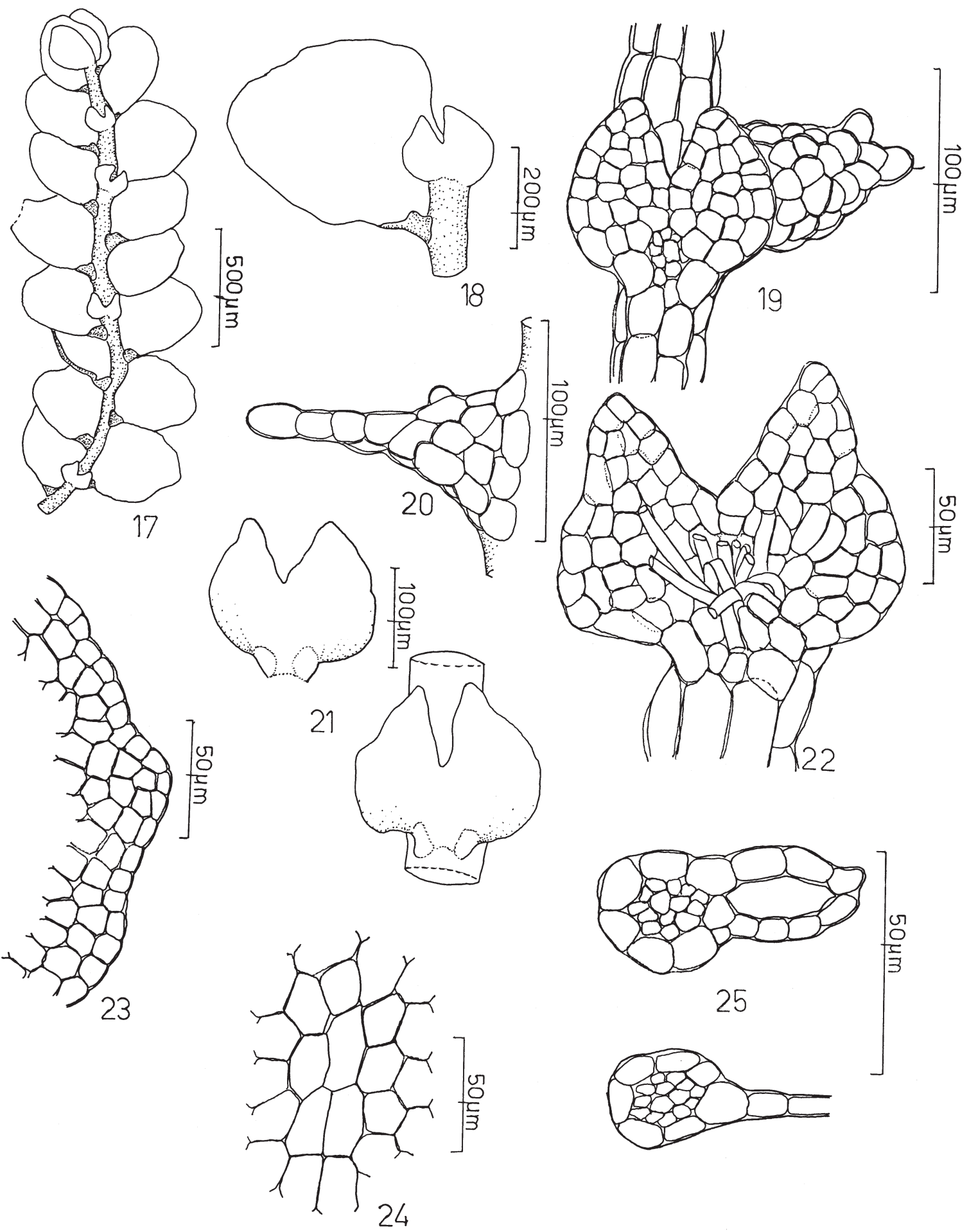

Figuras 17-25. Lejeunea immersa Spruce. 17. Gametófito, vista ventral. 18. Filídio e anfigastro. 19. Lóbulo e afigastro. 20. Lóbulo reduzido. 21. Anfigastros. 22. Detalhe do anfigastro. 23. Margem do lobo do filídio. 24. Células da lâmina. 25. Cortes transversais do caulídio (C. Bastos 4259).

Figuras 17-25. Lejeunea immersa Spruce. 17. Shoot, ventral view. 18. Leaf and underleaf. 19. Lobule and underleaf. 20. Reduced lobule. 21. Underleaves. 22. Detail of underleaf. 23. Leaf lobe margin. 24. Laminal cells. 25. Stem cross-sections (C. Bastos 4259). 
Material examinado: BRASIL. BAHIA: Aporá, km 134 da estrada de Alagoinhas para Olindina, 1-IV1976, D.M. Vital 5970 (SP); Morro do Chapéu, $11^{\circ} 39^{\prime} \mathrm{S}, 41^{\circ} 07^{\prime} \mathrm{W}, 17-\mathrm{V}-1978$, D.M. Vital 8035 (SP); Ilhéus, 1448'09”'S, 3902'04'W, zona urbana, Praça Seabra, 26-I-1980, O. Yano 2330 (SP); Feira de Santana, 12¹6'02"S, 38'57'39'W, zona urbana, Praça da Matriz, 23-X-1990, O. Yano et al. 15054

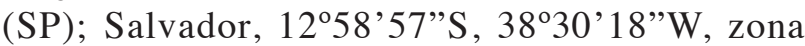
urbana, bairro do Cabula, 10-III-2002, C. Bastos 3163 (ALCB); idem, Av. Garibaldi, 20-IX-1991, C. Bastos 354 (ALCB); idem, Parque Zoobotânico, 5-IV-1996, C. Bastos 801 (ALCB); idem, Parque Metropolitano de Pituaçu, 4-VI-1999, C. Bastos 1515 (ALCB); idem, Parque Metropolitano do Abaeté, 30X-1997, C. Bastos 1030 (ALCB); São Francisco do Conde, Monte Recôncavo, 12³8'36”S, 38³7'59”W, Fazenda Engenho Madruga, 19-V-1991, C. Bastos 210 (ALCB); Jaguaripe, Jacuruna, 1302'02”S, 3850'50"W, 30-VI-1991, C. Bastos 271 (ALCB); Salinas da Margarida, Encarnação, 12 $2^{\circ} 55^{\prime} 58^{\prime \prime S}$, 3845'25'W, 8-IV-1993, C. Bastos 489 (ALCB); município de Camaçari, Arembepe, $12^{\circ} 45^{\prime} 52^{\prime \prime} \mathrm{S}$, 38'10'53"W, 10-VII-1997, C. Bastos 824 (ALCB); Guarajuba, 1241'49'S, 3807'47'W, 31-VII-1997, C. Bastos 883 (ALCB); Jauá, 1252'48”'S, 38¹8'18”'W, 21-V-1998, C. Bastos 1153 (ALCB); Esplanada, Vila de Baixio, 1208'44"S, 3743'24"W, 17-X-1997, C. Bastos 936 (ALCB); Mata de São João, Praia do Forte, 12³4'17"S, 3800'51'"W, 23-XII-1997, C. Bastos 1081 (ALCB); Entre Rios, Massarandupió, 12¹7'16"S, 3751'01'W, 23-VII-1998, C. Bastos 1459 (ALCB); Campus da UESC, Rodovia Ilhéus/

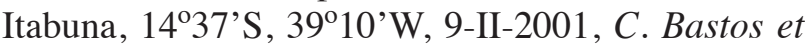
al. 2413 (ALCB); Porto Seguro, Arraial d'Ajuda, $16^{\circ} 28^{\prime} 30^{\prime}$ 'S, $39^{\circ} 03^{\prime} 46^{\prime} \mathrm{W}$, caminho para a praia do Apaga Fogo, 12-III-2001, C. Bastos \& S.B. Vilas Bôas-Bastos 2707 (ALCB); São Felipe, 12 ${ }^{\circ} 50^{\prime} 50$ 'S, 39'05'22"W, zona urbana, 12-VII-2001, C. Bastos \& S.B. Vilas Bôas-Bastos 3071 (ALCB); Miguel Calmon, Serra do Campo Limpo, Parque Estadual das Sete Passagens, Trilha do Vale do Jajai, $1000 \mathrm{~m}$ alt., 11'59'19"'S, 4053'00"W, 21-IV-2003, C. Bastos \& S.B. Vilas Bôas-Bastos 3286 (ALCB); Igrapiúna, Reserva Ecológica da Michelin, 1348'08"S, $39^{\circ} 10^{\prime} 03^{\prime}$ 'W, Mata da Cachoeira da Pancada Grande, 21-IV-2006, C. Bastos 4618 (ALCB).

Distribuição geográfica: América do Norte, América Central e América do Sul. Brasil: AC, AL, AM, BA, ES, MS, PA, PB, PE, RJ, SP.
Ambiente: Floresta Ombrófila, Floresta Estacional, Savana, Vegetação Pioneira com Influência Marinha, Fragmento Florestal Urbano, Sistema Agroflorestal e Zona Urbana.

Briocenose: corticícola, epíxila e casmófita.

Bem representada no Estado da Bahia, ocorrendo em várias localidades e crescendo em variados ambientes e substratos. É bastante comum em árvores da cidade de Salvador.

Lejeunea magnoliae Lindenb. \& Gottsche, Syn. Hepat.: 763. 1847.

Descrição e ilustração: Schuster (1980, como Lejeunea caespitosa Lindenb.)

Apresenta filídios contíguos a imbricados, margem inteira, ápice arredondado, anfigastros com lobos agudos a levemente lanceolados, sinus lunado a largamente agudo; ginoécio com brácteas inteiras, perianto com quilhas bem definidas, rostro evidente.

Material examinado: BRASIL. BAHIA: Eunápolis, Estação Veracruz, $16^{\circ} 22^{\prime} 47^{\prime}$ 'S, 39¹0'20"W, 9-IX1999, C. Bastos \& S.B. Vilas Bôas-Bastos 1725 (ALCB); Campus da UESC, Rodovia Ilhéus/Itabuna, $14^{\circ} 37^{\prime}$ 'S, 39 ${ }^{\circ} 10^{\prime} \mathrm{W}, 9-\mathrm{II}-2001$, C. Bastos et al. 2439 (ALCB); São Felipe, 1250'50”'S, 3905'22”'W, Serra da Copioba, $360 \mathrm{~m}$ alt., 12-VII-2001, C. Bastos \& S.B. Vilas Bôas-Bastos 2847 p.p. (ALCB); Miguel Calmon, Serra do Campo Limpo, Parque Estadual das Sete Passagens, Trilha do Vale do Jajai, $1.000 \mathrm{~m}$ alt., 11'59'19'S, 4053'00"W, 21-IV-2003, C. Bastos \& S.B. Vilas Bôas-Bastos 3355 (ALCB); Igrapiúna, Reserva Ecológica da Michelin, 13⒋ $08^{\circ}$ "S, $39^{\circ} 10^{\prime} 03$ 'W, Mata da Vila Cinco, 14-II-2006, $C$. Bastos 4360 (ALCB); idem, Mata de Pacangê, 8-II2007, C. Bastos 5017-D (ALCB).

Distribuição geográfica: África, América do Norte, América Central e América do Sul. Brasil: AC, BA, PA, RJ, SP (como Lejeunea caespitosa Lindenb.).

Ambiente: Floresta Ombrófila, Floresta Estacional e Sistema Agroflorestal.

Briocenose: corticícola e epíxila.

Os espécimes examinados no presente estudo serão aqui considerados no conceito de Lejeunea magnoliae, conforme consta na "Preliminary key to the genus Lejeunea in Brazil" (http://www.drehwald. info/Lejeunea/Key_Lejeunea_Brazil_30_April.pdf).

*Lejeunea oligoclada Spruce, Bull. Soc. Bot. France 36 (Suppl. Congrès Bot. 1889): 199. 1890. 
Figuras 26-31

Gametófitos pequenos, 460-624 $\mu$ m larg., pouco ramificados, ramos do tipo-Lejeunea. Caulídio com $60 \mu \mathrm{m}$ larg., em secção transversal com 7 células corticais, 4 células medulares. Filídios patentes a suberetos, contíguos; lobo ovalado a triangular, 240-300 × 200-210 $\mu \mathrm{m}$, margem anterior levemente arqueada, inteira, levemente crenulada, margem posterior reta, crenulada, ápice arredondado a agudo; células da lâmina hexgonais, 20-25 × 15-17 $\mu \mathrm{m}$, paredes delgadas, trigônios e espessamentos intermediários indistintos, oleocorpos pequenpos, finamente granulosos, do tipo-Jungermannia, ocelos ausentes; cutícula finamente papilosa; lóbulo ovalado, inflado, 100-120 × 80-88 $\mu \mathrm{m}$, margem livre involuta, dente apical oblongo, levemente falcado, margem apical curvada, raramente oblíqua, papila hialina proximal, quilha levemente arqueada. Anfigastros ovalados a rotundos, 102-120 $\mu \mathrm{m}$ larg., ca. 1,82,0 vezes a largura do caulídio, bífidos a $1 / 2$ de seu comprimento, distanciados, sinus agudo, base cuneada, linha de inserção arqueada. Merófito ventral com duas células de largura. Dióica. Androécio em curtos ramos, 2-3 pares de brácteas, lóbulos inflados, bractéola na base do ramo. Ginoécio não observado. Reprodução vegetativa por filídios caducos ou por formação de gemas, na margem do lobo dos filídios.

Material examinado: BRASIL. BAHIA: Miguel Calmon, Parque Estadual das Sete Passagens, $11^{\circ} 39^{\prime} \mathrm{S}$, 4053'W, 1000 m altitude, 23-IV-2003, C. Bastos \& S.B. Vilas Bôas-Bastos 3733 p.p. (ALCB); idem, 8-IX-2007, J. Ballejos 1708 p.p. (ALCB); Abaíra, Catolés, Serra do Barbado, 5-IX-2008, 1594 m alt., $13^{\circ} 17^{\prime} 27^{\prime} \mathrm{S}, 41^{\circ} 54^{\prime} 015^{\prime \prime} \mathrm{W}$, C. Bastos 5155 p.p. (ALCB); idem, 6-IX-2008, $1734 \mathrm{~m}$ alt., 13¹7'47's, 41'54'14”'W, C. Bastos 5222 p.p. (ALCB).

Distribuição geográfica: Brasil: Brasil. BA, ES, MG, RJ, SC, SP.

Ambiente: Floresta Estacional.

Briocenose: corticícola e epíxila.

Pode ser confundida com Lejeunea phyllobola, no entanto, o tamanho menor do gametófito e a cutícula finamente papilosa em Lejeunea oligoclada distingue as duas espécies. Na descrição original de Spruce (1890), é referida apenas a ocorrência "In Brasilia australis", sem especificar a localidade. Entretanto, de acordo com os dados de ReinerDrehwald \& Schäfer-Verwimp (2008), a localidade tipo é o Rio de Janeiro. Os espécimes examinados foram encontrados associados a Harpalejeunea stricta (Lindenb. \& Gottsche) Steph., Marchesinia brachiata (Sw.) Schiffn., Omphalanthus filiformis (Sw.) Nees e Plagiochila distinctifolia Lindenb. Foi erroneamente referida para a Bahia como Lejeunea ruthii (A. Evans) R.M. Schust. por Yano (2008).

Lejeunea perpapillosa E. Reiner \& Pôrto, Nova Hedwigia 85: 542. 2007.

Descrição e ilustração: Reiner-Drehwald \& Pôrto (2007).

Caracteriza-se pela cutícula papilosa, anfigastros com sinus profundo e largamente aberto, com multiplicação vegetativa por filídios caducos.

Material examinado: BRASIL. BAHIA: Igrapiúna, Reserva Ecológica da Michelin, 1348'08"S, 39¹0'03”W, Mata da Vila Cinco, 14-II-2006, C. Bastos 4379 (ALCB); idem, Mata da Cachoeira da Pancada Grande, 21-IV-2006, C. Bastos 450 p.p. (ALCB); idem, Mata do Meio, 7-II-2007, C. Bastos 4952 (ALCB); idem, Mata de Pacangê, 8-II-2007, $C$. Bastos 4997 p.p. (ALCB).

Distribuição geográfica: Brasil: BA, PE.

Ambiente: Floresta Ombrófila.

Briocenose: corticícola e rupícola.

Descrita apenas para os Estados da Bahia e de Pernambuco. Na Bahia, até o momento, restrita à área de coleta (Igrapiúna, Reserva da Michelin), porém, com alta ocorrência.

Lejeunea phyllobola Nees \& Mont. in Ramón de La Sagra, Hist. Phys. Cuba, Bot. Pl. Cell, 9: 471. 1842.

Descrição e ilustração: Reiner-Drehwald (2000).

Apresenta filídios ovalados, margem inteira a fracamente crenulada, anfigastros ovalados, lobos agudos, sinus agudo, base cuneada; dióicos; gionoécio com brácteas inteiras, perianto obovado-oblongo, 5-quilhado, rostro muito curto. Reprodução vegetativa caracteristicamente por filídios caducos, com gemas originando-se da margem dos filídios.

Material examinado: BRASIL. BAHIA: Cachoeira, Pedra do Cavalo, 12³4'55'S, 38 59'30'W, Fazenda Favela, 20-IX-1992, C. Bastos 441 (ALCB); Eunápolis, Estação Veracruz, $16^{\circ} 22^{\prime} 47^{\prime \prime S}, 39^{\circ} 10^{\prime} 20^{\prime \prime W}, 9-I X-$ 1999, S.B. Vilas Bôas-Bastos \& C. Bastos 1239 

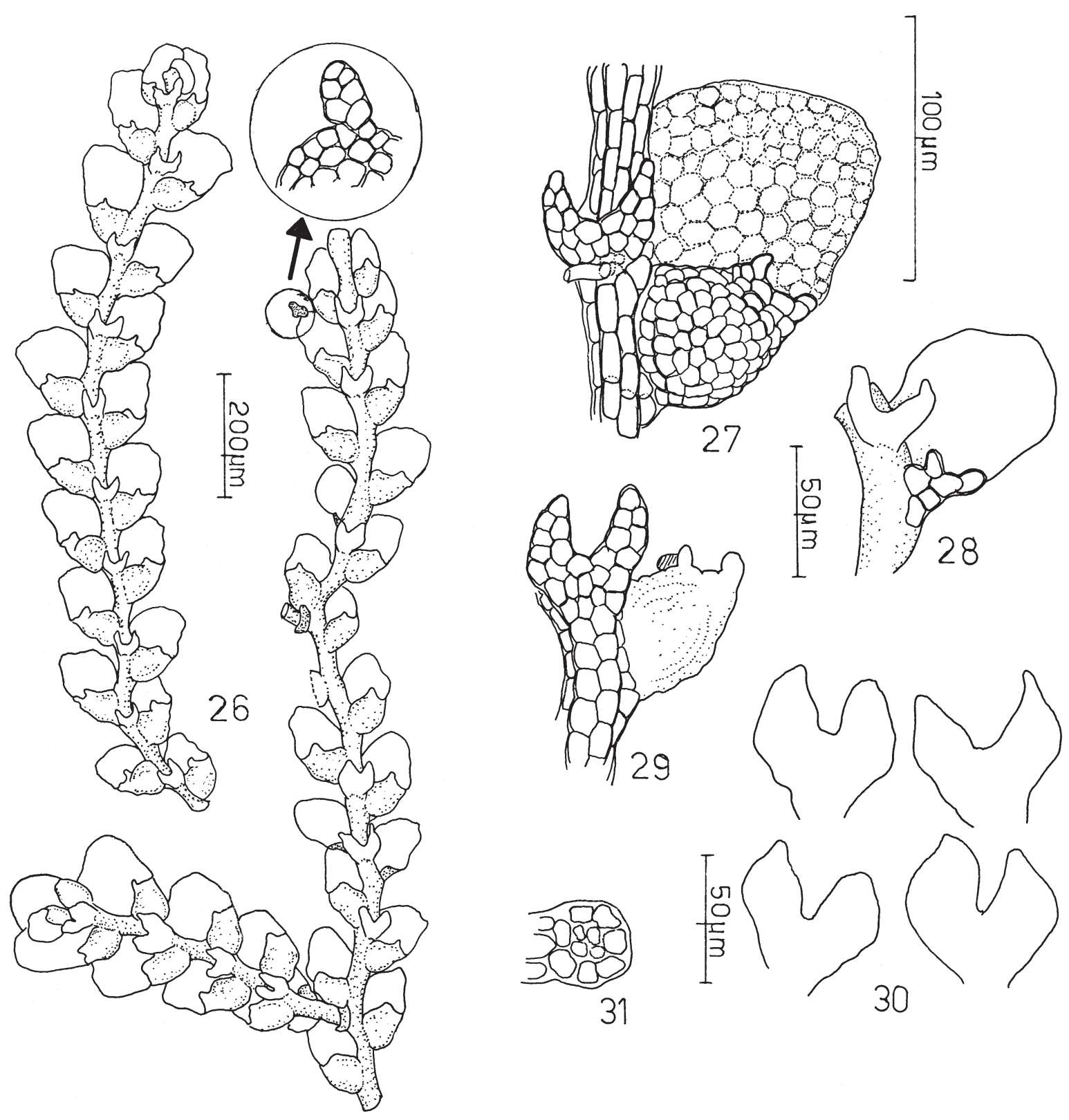

Figuras 26-31. Lejeunea oligoclada Spruce. 26. Gametófitos, vista ventral. 27. Filídio e anfigastro. 28. Anfigastro e lóbulo do filídio reduzido. 29. Anfigastro e lóbulo do filídio desenvolvido. 30. Anfigastros. 31. Corte transversal do caulídio (C. Bastos \& S.B. Vilas BôasBastos 3323).

Figures 26-31. Lejeunea oligoclada Spruce. 26. Shoot, ventral view. 27. Leaf and underleaf. 28. Underleaf and reduce lobule leaf. 29. Underleaf and normal lobule leaf. 30. Underleaves. 31. Stem cross-section (C. Bastos 3323). 
(ALCB); Campus da UESC, Rodovia Ilhéus/Itabuna, $14^{\circ} 37^{\prime}$ 'S , 14 ${ }^{\circ} 47^{\prime}$ 'S, 39 ${ }^{\circ} 10^{\prime} \mathrm{W}$, 9-II-2001, C. Bastos et al. 2501 (ALCB); Santa Cruz Cabrália, Fragmento Cara-branca, $16^{\circ} 16^{\prime} \mathrm{S}, 39^{\circ} 02^{\prime} \mathrm{W}, 9-\mathrm{III}-2001, C$. Bastos \& S.B. Vilas Bôas-Bastos 2619 (ALCB); Santa Terezinha, povoado de Pedra Branca, Serra da Jibóia, 1251'17'S, 39²8'30”'W, 12-III-2002, C. Bastos 3263 p.p. (ALCB); Miguel Calmon, Serra do Campo Limpo, Parque Estadual das Sete Passagens,

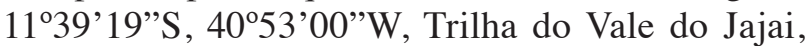
$1.000 \mathrm{~m}$ alt., 21-IV-2003, C. Bastos \& S.B. Vilas BôasBastos 3323 (ALCB); Igrapiúna, Reserva Ecológica da Michelin, 13\%48'08'S, 39 ${ }^{\circ} 10^{\prime}$ '03'W, Mata da Vila Cinco, 14-II-2006, C. Bastos 4144 (ALCB); idem, Mata da Cachoeira da Pancada Grande, 21-IV-2006, C. Bastos 4524 (ALCB).

Distribuição geográfica: América do Norte, América Central e América do Sul. Brasil: AC, AL, BA, ES, MS, PA, RJ, SP.

Ambiente: Floresta Ombrófila e Floresta Estacional.

Briocenose: corticícola e epíxila.

Bem representada na Bahia, é morfologicamente semelhante à Lejeunea oligoclada Spruce, porém a cutícula é lisa e a planta é um pouco maior.

*Lejeunea setiloba Spruce, Trans. \& Proc. Bot. Soc. Edinburgh 15: 281. 1884. (2000)

Descrição e ilustração: Reiner-Drehwald

Apresenta filídios ovalados, imbricados, margem inteira, anfigastros ovalados, lobos agudos, sinus agudo a lunado, profundo; dente apical do lóbulo caracteristicamente alongado, unisseriado a bisseriado.

Material examinado: BRASIL. BAHIA: Santa Bárbara, ca. $45 \mathrm{~km}$ de Feira de Santana, BR 116, 23-X-1990, O. Yano \& J.O. Pereira 15095 (SP).

Distribuição geográfica: América do Sul. Brasil: AM, BA, MS, SP.

Ambiente: Savana Estépica.

Briocenose: corticícola.

A espécie pode assemelhar-se a Lejeunea ptosimophylla C. Massal. quando apresenta dente apical do lóbulo bisseriado, e também por apresentar, ocasionalmente, anfigastros semi-caducos (apenas um dos lobos é destacado). Foi erroneamente referida como Lejeunea ptosimophylla por Bastos (2004), porém, em Lejeunea ptosimophylla o lóbulo do filídio é curto e o dente apical é caracteristicamente bisseriado e longo.

Lejeunea tapajosensis Spruce, Trans. \& Proc. Bot. Soc. Edinburgh 15: 223. 1884.

Descrição e ilustração: Reiner-Drehwald (2000).

Apresenta filídios oblongos a ovalados, margem inteira, anfigastros ovalados, lobos agudos, sinus agudo, base cuneada; ginoécio com brácteas inteiras, perianto obovado, 5-quilhado. Reprodução vegetativa caracteristicamente por filídios caducos; rizóides em geral presentes na margem dos filídios.

Material examinado: BRASIL. BAHIA: Cachoeira, Pedra do Cavalo, 12³4'55"S, 38 59'30"W, Fazenda Favela, 20-IX-1992, C. Bastos 446 (ALCB); Eunápolis, Estação Veracruz, 16 22'47''S, 39¹0'20"W, 10-III2001, C. Bastos \& S.B. Vilas Bôas-Bastos 2702 (ALCB); Itacaré, Engenhoca, $14^{\circ} 20^{\prime} 58^{\prime}$ 'S , 38 $8^{\circ} 59^{\prime} 59^{\prime \prime} \mathrm{W}$, ca. 12 $\mathrm{km}$ ao sul de Itacaré, 8-II-2001, C. Bastos \& S.B. Vilas Bôas-Bastos 2371 (ALCB); Campus da UESC, Rodovia Ilhéus/Itabuna, $14^{\circ} 37^{\prime} \mathrm{S}$ e $14^{\circ} 47^{\prime} \mathrm{S}, 39^{\circ} 10^{\prime} \mathrm{W}$, 9-II-2001, C. Bastos et al. 2548 (ALCB); Santa Cruz Cabrália, Fragmento Cara-branca, $16^{\circ} 16^{\prime} \mathrm{S}, 39^{\circ} 02^{\prime} \mathrm{W}$, 9-III-2001, C. Bastos \& S.B. Vilas Bôas-Bastos 3110 (ALCB); Igrapiúna, Reserva Ecológica da Michelin, $13^{\circ} 48^{\prime} 08^{\prime}$ 'S, 39 $19^{\circ}$ '03' W, Mata da Vila Cinco, 14II-2006, C. Bastos 4267 (ALCB); idem, Mata da Cachoeira da Pancada Grande, 21-IV-2006, C. Bastos 4558 (ALCB); idem, Mata do meio, 7-II-2007, $C$. Bastos 4975 (ALCB).

Distribuição geográfica: América Central e América do Sul. Brasil: AC, BA, PA, PE.

Ambiente: Floresta Ombrófila, Floresta Estacional e Sistema Agroflorestal.

Briocenose: corticícola, epífila e epíxila.

A espécie tem boa representatividade na Bahia, ocorrendo em florestas estacionais e ombrófilas de terras baixas, em geral com alta ocorrência.

Lejeunea trinitensis Lindenb. in Gottsche, Lindenb. \& Nees, Syn. Hepat.: 381. 1845.

Descrição e ilustração: Reiner-Drehwald (2000).

Apresenta filídios ovalados, contíguos, margem inteira, anfigastros oblongos a ovalados, lobos lanceolados a agudos, sinus largamente agudo, profundo, base cuneada, dente apical do lóbulo 
caracteristicamente alongado, unisseriado a bisseriado, formado por 7-9 células de comprimento. Autóica; androécio com 2-4 pares de brácteas, bractéolas na base do ramo; ginoécio com brácteas inteiras, perianto obovado, 5-quilhado, quilhas inteiras.

Material examinado: BRASIL. BAHIA: Milagres, ao

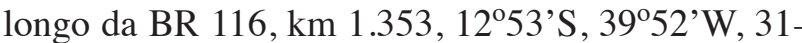
III-1976, D.M. Vital 5939 (SP); Itapicuru, ca. 4 km SW de Itapicuru, 1-IV-1976, D.M. Vital 5984 (SP); Feira de Santana, $12^{\circ} 16^{\prime} 02^{\prime \prime}$,, $38^{\circ} 57^{\prime} 39^{\prime \prime} \mathrm{W}$, perto da ponte junto à represa, 23-X-1990, O. Yano et al. 15056 (SP); Santa Bárbara, ca. 30 km de Fira de Santana, BR 116, 23-X-1990, O. Yano \& J.O. Pereira 15016 (SP); Ipirá, 1210'24”S, 3943'51'"W, Fazenda Nova Favela, 17-IX-1995, C. Bastos et al. 743 (ALCB); São Felipe, 1250'50"S, 3905'22'W, zona urbana, 12-VII-2001, C. Bastos \& S.B. Vilas Bôas-Bastos 3080a (ALCB); Salvador, 1253'57”S, 38³0'18”'W, Campus Universitário-UFBA, Ondina, zona urbana, 23-III-2004, C. Bastos 3797 (ALCB).

Distribuição geográfica: África, América do Norte e América do Sul. Brasil: AC, AM, BA, MT, MS, PE, PR, RJ, SE.

Ambiente: Savana Estépica e Zona Urbana.

Briocenose: corticícola.

Não tem sido extensivamente coletada na Bahia, ocorrendo em ambiente de caatinga e em zona urbana.

O gênero Lejeunea mostrou ser bem representado no Estado da Bahia, uma vez que das 41 espécies referidas para o Brasil (Reiner-Drehwald 2007), 21 $(51,2 \%)$ ocorreram no estado da Bahia, sendo que quatro constituem novas referências para o Estado. As espécies encontradas na Bahia ocorreram em várias localidades e em diferentes ambientes, crescendo em variados substratos.

Das 21 espécies reconhecidas para o Estado da Bahia, 17 (85,7\%) foram corticícolas, nove $(42,8 \%)$ epíxilas, oito $(38,1 \%)$ rupícolas, sete $(33,3 \%)$ epífilas, duas $(9,5 \%)$ terrícolas e apenas uma $(4,7 \%)$ casmófita (comunidade que cresce sobre substratos artificiais, de natureza rochosa, tais como concreto e argamassa), em zona urbana, indicando que os substratos preferenciais foram tronco vivo e tronco morto. Foi observado que apenas seis $(28,6 \%)$ ocorreram em um único substrato (tronco vivo), e as demais $(71,4 \%)$ ocorreram em mais de um substrato, sendo que, dessas, oito $(53,3 \%)$ cresceram em mais de dois substratos e sete $(46,7 \%)$ em apenas dois substratos. O baixo número de espécies exclusivas a um dado substrato (apenas cinco), demonstra o largo espectro ecológico do gênero na Bahia.

Das espécies encontradas, 16 ocorreram em floresta ombrófila, sendo oito $(38,1 \%)$ exclusivas desse ambiente, 10 em floresta estacional, com três exclusivas $(14,3 \%)$, quatro em Fragmento Florestal Urbano e Zona Urbana (nenhuma exclusiva em ambos os ambientes), três em Savana e Sistema Agroflorestal (nenhuma exclusiva), duas em Savana Estépica (caatinga) com uma exclusiva $(4,8 \%)$ e uma em Vegetação Pioneira com Influência Marinha (restinga), não exclusiva desse ambiente. Como um todo, 12 espécies foram exclusivas e nove compartilhadas com as diferentes formações vegetais. Lejeunea flava e Lejeunea laetevirens foram as espécies com maior amplitude ecológica, ocorrendo em cinco e sete diferentes formações vegetais, respectivamente.

Em relação à distribuição geográfica, 11 espécies $(53,4 \%)$ ocorrem apenas na América Tropical, e apenas uma $(4,7 \%)$ é pantropical, três $(14,2 \%)$ têm distribuição Afro-Americana, e oito $(30,1 \%)$ apresentaram distribuição sub-tropical e tropical, com ocorrência na América do Norte e Argentina. Das espécies neotropicais, seis $(28,6 \% \%)$ são endêmicas do Brasil (Lejeunea grossiretis, Lejeunea grossitexta, Lejeunea perpapillosa, Lejeunea oligoclada, Lejeunea setiloba e Lejeunea tapajosensis). No Brasil, o gênero é bem representado, sendo que 11 espécies têm ampla distribuição, ocorrendo em mais de três Estados, e sete espécies apresentam distribuição restrita a três Estados, e Lejeunea grossiretis e Lejeunea elliottii, até o momento, só têm registro para a Bahia. No entanto, o gênero pode ter distribuição mais ampla no Brasil, e o quadro atual pode ser resultante da escassez de coletas em alguns Estados ou ambientes brasileiros, bem como da dificuldade de identificação de algumas espécies. A intensificação dos inventários florísticos poderá mostrar uma situação mais real para esse e outros gêneros de briófitas que ocorrem no Brasil.

Lejeunea é um gênero taxonomicamente difícil, e a identificação segura da maioria de suas espécies só é possível se o material estiver com perianto. O estudo taxonômico das espécies que ocorrem no Brasil é necessário para se ter uma visão mais real da representatividade do gênero no país.

\section{Agradecimentos}

Os autores são especialmente gratos aos Curadores dos Herbários CEPEC, HUEFS e SP por tornar 
disponível o material para estudo; Dra. M.E. ReinerDrehwald pelo envio de material bibliográfico; Diretoria da Veracel Celulose pela autorização e apoio logístico e de pessoal para a realização de coleta na Estação Veracruz; Plantações Michelin da Bahia LTDA (Convênio UFBA-Plantações Michelin da Bahia) pela autorização e apoio logístico e de pessoal para a realização de coletas na Reserva Ecológica da Michelin; SEMARH pela concessão da autorização para coletas realizadas na APA Serra do Barbado; a Bióloga Ms Silvana Brito Vilas Bôas-Bastos pela confecção das ilustrações; ao PICDT/CAPES (Programa de Incentivo à Capacitação Docente/ Coordenação de Aperfeiçoamento de Pessoal) pela concessão da Bolsa ao primeiro autor.

\section{Literatura citada}

Alvarenga, L.D., Silva, M.P.P., Oliveira, J.R.M.P. \& Porto, K.C. 2007. Novas ocorrências de Briófitas para Pernambuco, Brasil. Acta Botanica Brasílica 21: 349-360.

Bastos, C.J.P. \& Vilas Bôas-Bastos, S.B. 2000. Variações morfológicas do lóbulo em Lejeunea glaucescens Gott. (Lejeuneaceae, Hepaticopsida). Acta Botanica Malacitana 25: 73-80.

Bastos, C.J.P. \& Yano, O. 2004. New records of Lejeuneaceae (Marchantiophyta) for the Brazil. Acta Botanica Malacitana 29: 13-21.

Bastos, C.J.P. \& Yano, O. 2006. Lejeuneaceae holostipas (Marchantiophyta) no Estado da Bahia, Brasil. Acta Botanica Brasilica 20: 687-700.

CEI/CONDER - Centro de Estatistica e Informação/ Companhia do Desenvolvimento da Região Metropolitana de Salvador. 1994. Informações básicas dos municípios baianos: Região Metropolitana de Salvador. CEI/CONDER, Secretaria do Planejamento, Ciência e Tecnologia, Salvador.

Fudali,E. 2000. Some open questions of the bryophytes of urban areas and their response to urbanization's impact. Perspectives in Environmental Sciences 2: 14-18.

Fudali, E. 2001. The ecological structure of the bryoflora of wroclaw's parks and cemeteries in relation to their localization and origin. Acta Societatis Botanicorum Poloniae 70: 229-235.

Gradstein, S.R. \& Costa, D.P. 2003. The Hepaticae and Anthocerotae of Brazil. Memoirs of the New York Botanical Garden 87: 1-318.

Reiner-Drehwald, M.E. 1999. Catalogue of the genus Lejeunea Lib. (Hepaticae) of Latin America. Bryophytorum Bibliotheca 54: 1-101.

Reiner-Drehwald, M.E. 2000. Las Lejeuneaceae (Hepaticae) de Misiones, Argentina VI. Lejeunea y Taxilejeunea. Tropical Bryology 19: 81-131.

Reiner-Drehwald, M.E. 2007. Preliminary key to the genus Lejeunea in Brazil (draft version 30 April 2007). http://www.drehwald.info/Lejeunea/Key_Lejeunea_ Brazil_30_April.pdf (acesso em 26.4.2007).

Reiner-Drehwald, M.E.\& Goda,A. 2000. Revision of the genus Crossotolejeunea (Lejeuneaceae, Hepaticae). The Journal of the Hattori Botanical Laboratory 89: 1-54.

Reiner-Drehwald, M.E. \& Ilkiu-Borges, A.L. 2007. Lejeunea huctumalcensis, a widely distributed Lejeuneaceae from Neotropics, and its relation to Ceratolejeunea. The Bryologist 110: 465-474.

Reiner-Drehwald, M.E. \& Pôrto, K.C. 2007. Lejeunea perpapillosa (Lejeuneaceae), a new species from northeastern Brazil. Nova Hedwigia 85: 541-546.

Reiner-Drehwald, M.E. \& Schäfer-Verwimp, A. 2008. Lejeunea oligoclada and L. rionegrensis (Lejeuneaceae) in tropical America: new data on morphology and geographical distribution. Nova Hedwigia 87: 175184.

Schuster, R.M. 1980. Hepaticae and Anthocerotae of North America east Handredht Meridian. Columbia University Prees, New York.

Veloso, H.P., Rangel Filho, A.L.R. \& Lima, J.C.A. 1991. Classificação da vegetação brasileira adaptada a um sistema universal. IBGE, Departamento de Recursos Naturais e Estudos Ambientais, Rio de Janeiro

Yano, O. 2006. Novas adições ao catálogo de Briófitas Brasileiras. Boletim do Instituto de Botânica 17: 1-142.

Yano, O. 2008. Catálogo de Antóceros e Hepáticas Brasileiros: literatra original, basiônimo, localidadetipo e distribuição geográfica. Boletim do Instituto de Botânica 19: 1-110. 